\title{
Correction to: Survivorship and prognostic factors for pleomorphic liposarcoma: a population-based study
}

\author{
Lu Wan ${ }^{1,2,3}$, Chao Tu ${ }^{1,3}$, Lin Qi ${ }^{1,3}$ and Zhihong Li $i^{1,3^{*}}$
}

\section{Correction to: J Orthop Surg Res 16, 175 (2021)}

https://doi.org/10.1186/s13018-021-02327-3

Following the publication of the original article [1], author noticed that the email addresses of 2 authors are captured in the correspondence field. Lu Wan and Chao $\mathrm{Tu}$ are not co-corresponding authors for this paper. Hence, correspondence symbol has been deleted from the author group as well (as shown above).

The original article has been corrected.

\begin{abstract}
Author details
'Department of Orthopedics, The Second Xiangya Hospital, Central South University, 139 Renming Road, Changsha 410011, Hunan, People's Republic of China. ${ }^{2}$ Vaccine and Immunotherapy Center, Infectious Diseases Division, Department of Medicine, Massachusetts General Hospital and Harvard Medical School, 149 13th Street, Charlestown, MA 02129, USA. ${ }^{3}$ Key Laboratory of Tumor Models and Individualized Medicine, The Second Xiangya Hospital, Central South University, 139 Renming Road, Changsha 410011, Hunan, People's Republic of China.
\end{abstract}

Published online: 29 March 2021

\section{Reference}

1. Wan L, Tu C, Qi L, et al. Survivorship and prognostic factors for pleomorphic liposarcoma: a population-based study. J Orthop Surg Res. 2021;16(1):175. https://doi.org/10.1186/s13018-021-02327-3.

The original article can be found online at https://doi.org/10.1186/s13018021-02327-3.

*Correspondence: lizhihong@csu.edu.cn

'Department of Orthopedics, The Second Xiangya Hospital, Central South University, 139 Renming Road, Changsha 410011, Hunan, People's Republic of China

${ }^{3}$ Key Laboratory of Tumor Models and Individualized Medicine, The Second Xiangya Hospital, Central South University, 139 Renming Road, Changsha 410011, Hunan, People's Republic of China

Full list of author information is available at the end of the article

(c) The Author(s). 2021 Open Access This article is licensed under a Creative Commons Attribution 4.0 International License, which permits use, sharing, adaptation, distribution and reproduction in any medium or format, as long as you give appropriate credit to the original author(s) and the source, provide a link to the Creative Commons licence, and indicate if changes were made. The images or other third party material in this article are included in the article's Creative Commons licence, unless indicated otherwise in a credit line to the material. If material is not included in the article's Creative Commons licence and your intended use is not permitted by statutory regulation or exceeds the permitted use, you will need to obtain permission directly from the copyright holder. To view a copy of this licence, visit http://creativecommons.org/licenses/by/4.0/ The Creative Commons Public Domain Dedication waiver (http://creativecommons.org/publicdomain/zero/1.0/) applies to the data made available in this article, unless otherwise stated in a credit line to the data. 